\title{
QUALITATIVE ANALYSIS OF RESILIENCE IN CHINESE FAMILIES OF CHILDREN WITH HEARING IMPAIRMENT
}

\author{
Liu Shenglin, Zheng Linying
}

\begin{abstract}
Children' hearing impairments not only impact on themselves, but also influence all aspects of family life. Family resilience describes the path how family adapts and thrives in the face of stress, including the reality of having a child with hearing impairment. This study adopts semi-structured interview and qualitative analysis methods associated with grounded theory to analyze the experiences of seven resilient Chinese families with hearing-impaired children. It explores themes of the drive force for diagnosis of hearing loss, the families' reactions to the diagnosis, the difficulties families experienced during parenting and the strategies used to cope with childhood hearing impairment in Chinese context. Eventually the limitations of research are discussed.
\end{abstract}

\section{Key words}

Qualitative analysis, resilience, Chinese family, children with hearing impairment.

\section{Kvalitativní analýza resilience čínských rodin s dětmi s postižením sluchu}

\section{Resumé}

Sluchové postižení dítěte nemá vliv pouze na dítě samotné, ale také na život rodiny. Resilience rodiny je výsledkem úspěšného vyrovnání se stresem, souvisejícím se skutečností, že se narodilo dítě se sluchovým postižením. Tato studie zpracovává polostrukturované rozhovory a kvalitativní analýzu sedmi takovýchto čínských rodin. Zabývá se důvody, které vedly k zahájení diagnostického procesu, reakcí rodiny na výsledek diagnózy, obtížím, které rodiče překonávali, a strategiemi, které rodiče volili k vyrovnání se sluchovým postižením dítěte. Ve studii jsou také podchycena omezení prováděného výzkumu. 


\section{Klíčová slova}

Kvalitativní analýza, schopnost přizpůsobit se, čínská rodina, dítě se sluchovým postižením.

\section{Introduction}

Family is the central social context within which the development of the individual child occurs. Family involvement in education is especially important for children with handicaps including hearing impairment. The study of history of deaf education and those successful deaf individuals have revealed that parental involvement in both formal and informal education is one of the best predicator of children's academic success (Marschark et al., 2002). However, accumulated body of knowledge about the impact of hearing impairment on a family has demonstrated that it is the family, not the child himself or herself, that is in turmoil (Gregory and Knight, 1998). Indeed, as United Nations High Commissioner for Human Rights proposed in Convention on the Right of the Child, the family as the fundamental group of society and the natural environment for the growth and well-being of all its members, especially for children, should be afforded the necessary protection and assistance so that it can fully assume its responsibilities within the community (Office of the United Nations High Commissioner for Human Rights, 1989). It is insightful that the family with children of any handicaps, including hearing impairment, should be supported to be with resilience by community or society before they can have ability to play their social role.

Resilience is the ability to withstand and rebound from disruptive life challenges, it involves dynamic processes fostering positive adaptation within the context of significant adversity (Walsh, 2003). Over the past decades, the research on resilience has gained prominence as a branch to study the processes and mechanisms through which exposure to risk factors may be associated with individual's positive and negative outcomes (e.g. Werner, 1995; Murphy, 2008). Recent years' researches on resilience have been extended from individuals who are at-risk in variety of conditions, ranging from living in poverty, exposure to parental abuse and parental death alike, to the families which as a function unit, also encounter various stressful events, such as unwanted health - related crises, unexpected life events or changes. In general, regardless of individuals or families, the core question of resilience research is "what accounts for why some stay healthy and do well in the face of risk and adversity and others do not?" (Patterson, 2002, p. 360). 
According to Hann et al. (2002) family resilience describes the path a family follows as it adapts and prospers in the face of stress, both in the present and over time. From the point of view of family system theory, family is a system which is dynamic and holistic. There is no doubt that the birth of a child with hearing impairment or having a hearing-impaired child presents special challenges to the most hearing families because most cases of hearing impairment are not hereditary, many hearing impaired children will have congenital or early-onset hearing loss that are totally unexpected (and usually unrecognized for some time) by their parents. Consequently, the presence of hearing impairment in a family has the potential to affect all area of family life including family interaction, family resource, parenting and support for child. (Jackson and Turnbull, 2004). However, no matter how hard the situation is, in any social context, there always exist some families who can cope with hearing impairment successfully and be resilient while others not. Despite numerous studies have explored the experience of families of children with hearing impairment in western or industrialized countries, few studies, if any, have been conducted to examine the experience of Chinese families from a completely different social cultural background. This study attempts to present thick rich experiences from the perspectives of caregivers of children with hearing impairment and to increase our understanding of how families in Chinese social context adapt to the challenge of having a child with hearing-impairment and fostering them. Specifically, this study has tried to answer the following questions: how Chinese families react to the diagnosis of hearing loss, what difficulties they will experience in parenting, what strategies they have used to deal with the challenges resulted from children's hearing loss. The answers to these questions will inform the professionals in special education field and policy-makers in inside and outside of China.

\section{Method}

This study was a follow-up part of a comprehensive questionnaire survey for my Ph.D. dissertation and it aimed to better explore some questions which is less amenable to quantitative comparison. It mainly used semi-structured interview and some of qualitative analysis methods associated with grounded theory (Strauss \& Corbin, 1998, 2008) to collect data and analyze data. In recent years, qualitative methods have become more widely used to allow holistic descriptions of individuals or families' experience in some specific condition. Like other qualitative problems, the nature of the topic of this study, how families adapted 
to the challenge facing families with hearing impairment could not be suited to quantitative measures. This study initially started with an open and free talk between authors and some parents who attended a lecture which was given by the first author. Touched by experience of one resilient family struggling with the adverse impacts of hearing impairment on them, the concept of resilience came out in researchers' mind. To get more accurate and detailed experiences from diversified family background, two researchers eventually planned to recruit more resilient families to participate in the qualitative research to deepen and richen the questionnaire study. Within the general topic of how families of children with hearing impairment in the Chinese context adapt to reality, several questions in the interview guide had been asked via face to face personal interview. These questions included: (1) How was the hearing impairment diagnosed? (2) How did your family respond to the diagnosis? (3) What difficulties had your family experienced during the parenting? (4) What supports had your family got to help you deal with the child's hearing impairment? (5) What strategies has your family used to adapt to the reality of having a child with hearing impairment? All the interviews were recorded and transcribed shortly after. After collecting the data, the raw data spoken in Sichuan accent mandarin was translated into written raw data in general Chinese mandarin word by word. The interview and raw data collecting were completed by the second author Zheng Linying, a graduate student applying for master degree in special education in Sichuan Normal University in China. To avoid taking for granted subjectively and to reach agreement in coding, the qualitative analyses were completed by two authors using open coding, axial coding and comparative analysis again and again. According to Strauss and Corbin $(1998,2008)$, we used open coding to break data apart line by line and delineated concepts to stand for blocks of raw data in terms of their properties and dimensions. After open coding, we went on relating concepts to each other and labelled them as some categories. Then we used comparative analysis to compare categories from different families for similarities and differences. At last we grouped our understanding of experiences of family experience with childhood hearing impairment in the Chinese context into four themes: the process of diagnosis, reactions to the diagnosis, difficulties in parenting and strategies used to coping with children's hearing impairment. 


\section{Participants}

The main caregivers of children from resilient families judged by their responses in the questionnaire of families with hearing impaired children were invited to participate. Simply put, in this study the resilient families should satisfy the following requirements: 1) accepting well-up till to the time of participation family accepted child's hearing impairment basically and felt peace in family; 2) functioning well - involving keeping intact and meeting the members' economic needs, daily care needs, affection needs, educational needs, specifically, doing everything affordable and possible to promote children's potential development; 3) expecting well - believing in child's future, having self-efficacy in dealing with the future crisis. According to the above requirements, seven families were selected and would like to take part in the interview with consent. They were from two educational agencies, the Chengdu Rehabilitation and Education Center (CREC) for disabled preschoolers in Chengdu, the capital city of Sichuan Province, and Luxian Special School in Luxian, a agricultural county in Sichuan Province. As a whole, compared with other cities and counties in the eastern coastal regions or other developed areas, Chengdu and Luxian, two regions located in the western area of China, were relatively undeveloped in economy and social culture. However, from another point of view of representability, the families from two regions, one urban area, one rural area, may be more likely to be representative and suitable samples to study the Chinese families. For the convenience of participants, all interviews took place in the special school or rehabilitation center where the participant caregivers sent child to special teachers or trainers. The caregivers were encouraged to share their perspectives according to the level of comfort and to focus on the issues of importance to them based on the experience in caring for child. In order to be confidential and to be convenient for further analysis, the seven participant children are given pseudonym of Bao, Hang, Shuai, Mnan, Wang, Lulu, Luhua. The key demographic and clinical characteristics of the participant family and children were detailed in Table 1 and Table 2. 
Table 1 Characteristic of participant children

\begin{tabular}{ccccccc}
\hline Name & Age & Gender & $\begin{array}{c}\text { Degree of } \\
\text { hearing loss }\end{array}$ & $\begin{array}{c}\text { Age at } \\
\text { diagnosis }\end{array}$ & $\begin{array}{c}\text { Sensory } \\
\text { device }\end{array}$ & $\begin{array}{c}\text { Communication } \\
\text { method }\end{array}$ \\
\hline Bao & 53 months & Boy & $100 \mathrm{~dB}$ & 6 months & HA \& CI & Oral \\
Hang & 45 months & Boy & $>90 \mathrm{~dB}$ & 12 months & Ha \& CI & Oral \\
Shuai & 58 months & Boy & $>110 \mathrm{~dB}$ & 45 months & HA & Mixed \\
Mnan & 37 months & Boy & $>110 \mathrm{~dB}$ & 20 months & HA & Natural \\
& & & & & & gesture \\
Wang & 48 months & Boy & $>110 \mathrm{~dB}$ & 25 months & CI & Oral \\
Lulu & 72 months & Boy & not clear & 12 months & None & CSL \\
Luhua & 132 months & Girl & not clear & 12 months & None & Written and \\
& & & & & & CSL \\
\hline
\end{tabular}

Note: $\mathrm{HA}=$ Hearing Aids; $\mathrm{CI}=$ Cochlear Implants; Mixed = Natural gesture plus spoken language, $\mathrm{CSL}=$ Chinese Sign Language

Table 2 Demographic characteristics of participant families

\begin{tabular}{cccccc}
\hline Name & Caregiver & $\begin{array}{c}\text { Parental } \\
\text { hearing }\end{array}$ & $\begin{array}{c}\text { Community } \\
\text { type }\end{array}$ & $\begin{array}{c}\text { Educational } \\
\text { attainment }\end{array}$ & $\begin{array}{c}\text { Family } \\
\text { income }\end{array}$ \\
\hline Bao & Grandma & Normal & Urban & University & Middle \\
Hang & Grandma & Normal & Suburb & Middle school & Low \\
Shuai & Aunt & Normal & Rural & Middle school & Low \\
Mnan & Mother & Normal & Urban & University & Middle \\
Wang & Grandma-in-law & Normal & Suburb & Middle school & Low \\
Lulu & Mother & Normal & Rural & Middle school & Low \\
Luhua & Mother & Normal & Rural & Middle school & Low \\
\hline
\end{tabular}

Note: educational attainment $=$ highest educational attainment among family members

\section{Results}

Based on the developmental process of families experiencing children's hearing impairment, the findings of this study were formulated into the following themes: diagnosis and drive force for diagnosis, family reactions to the diagnosis, the difficulties families experienced while parenting their hearing-impaired children, strategies of family coping with children's handicaps in terms of the shared experience from the main caregivers of seven participant families: 


\section{Diagnosis and drive force for diagnosis}

Early and accurate identification of hearing loss is critical to the child's overall development and family coping with hearing impairment. All participant families expressed the view that newborn hearing screening services should be desired to be an important part of overall support services for children with hearing loss. However, in reality the diagnoses or identifications of hearing loss in seven families proceeded with in their own way differently and were driven by different forces.

Parents were often the most effective identification sources. Luhua, the eldest child of among seven children, who was 11 years old from the Luxian countryside, her hearing loss was identified around her one year old because of her responsive mother. "I felt she had problem in hearing by intuition. She appeared to have no response to my voice. So I and my husband sent her to the affiliated hospital of Luzhou Medical Colleage" she stated, "but up till to now, I did not know exactly the degree of hearing loss. I simply remembered that the doctor told us 'your child has severe hearing loss'." Like Luhua, Lulu's hearing loss was also firstly identified by his mother and diagnosed in hospital after one year old.

Mnan's mother shared her suspicion and made a slight complaint against the doctor's suggestion with the interviewer: "I had some suspicion about his hearing around his one and half years old because he can not speak. Then I went to the local hospital near my home and told the doctor my suspicion of his lag in language development and communication problem between us. After simple observation and comparison with behavioral checklist of autism, the doctor simply told me that he had no sign of autism and let me go on with observing his behavior. With the hope that he was just a boy opening mouth later, we delayed his diagnosis till he was two years old."

Both Wang's grandma- in-law and Shuai's aunt recognized the two children's hearing loss earlier by their experience of parenting children, yet because of their parent's self deceiving the diagnosis of two children's hearing loss were delayed. As Wang's grandma-in-law recalled: "when I told my suspicion of Wang' hearing loss to my son-in-law and my daughter, they self-deceived themselves that both of parent are normal, there was no reason for his deafness. At last, supported by the more apparent signs of no response to human voice and no locating reaction to sounds, more importantly, moved by my determination, the diagnosis was implemented when he was 25 months old." 
With the emergence of implementing newborn hearing screening in China after entering new century, some children benefited from such new technology revolution. Both Bao and Hang' were screened as positive in hearing loss which was one part of newborn disease screening paid by family at their birth. At last Bao's hearing loss was diagnosed accurately when he was six months old while Hang got his diagnosis when he was twelve months old.

Putting together the data many factors can be found to contribute to the time of diagnosis of children hearing loss. There is no doubt that hearing technique is important factor, but more important drive force for early diagnosis is responsiveness of caregivers and attentions paid to children's health.

\section{Family reactions to the diagnosis}

Seven families in this study were families of parents with normal hearing. Children's hearing losses were completely unexpected to them and created rigid family crisis. Though some families had some suspicions of children hearing loss earlier, all seven families demonstrated various kinds of intense negative emotional reactions to the diagnosis. For example, when Hang's grandma was asked how her family reacted to the diagnosis, she stated: "the whole family was overwhelmed with the bad news and all the families members, father, mother, and grandparents, wept their heart out." Further she explained: "It was unfair, our families didn't do anything evil, why we were punished by being given a child with such a handicap?" According to the parent experience, the most salient reactions of seven families and the focus reasons for their reaction were detailed in Table 3.

Table 3 The most salient reaction to diagnosis and focus reason

\begin{tabular}{|c|c|c|}
\hline $\begin{array}{l}\text { Family's } \\
\text { name }\end{array}$ & $\begin{array}{l}\text { Most salient reaction } \\
\text { to diagnosis }\end{array}$ & The focus reason for reaction \\
\hline Bao & Despair & All family members have no experience with deafness \\
\hline Hang & Grief & It's unfair, why we are given a child with deafness \\
\hline Shuai & Denial & The child will be normal over time \\
\hline Mnan & Shock & $\begin{array}{l}\text { We have some suspicion but the diagnosis is beyond my } \\
\text { expectation }\end{array}$ \\
\hline Wang & Anger & Why our child is abnormal while others not \\
\hline Lulu & Grief & Deafness means both child and parent have no future \\
\hline Luhua & Grief & $\begin{array}{l}\text { Both our families have no history of deafness and it is shame } \\
\text { to speak to others }\end{array}$ \\
\hline
\end{tabular}




\section{The difficulties families experience while parenting the children}

The children's hearing loss is not an acute event which happens and its impact will be ended at a particular point of time. In contrast it is chronic stress through long drawn-out process which may well produce marked challenges on family and which may continue to produce substantial difficulties on family. While recalling the images of conducting interview and working with the data of conversations, the main issue or theme that kept coming out in the mind was "difficulty" and experiencing difficulty was a constant day-to-day affair. The deepest impression of interview was that all participant caregivers looked fine and strong on the outside, but when they sat down to talk, all caregivers wanted to cry. Indeed, every difficult family was difficult in its own way.

Difficulty in communication with children

Because of the direct impact of hearing loss, seven caregivers expressed the more or less frustrations with communication with children. For Shuai, who was 58 months old, with profound hearing loss, but without systematic learning of sign language and without help of appropriate hearing device, his aunt described a large amount of experience about their communication difficulties: "sometimes he could understand what I said, sometimes he could not. Because of his severity of hearing loss, most of time he could not hear what I said. We used natural gesture and guess to communicate. It was more difficult for him to express his ideas. Every time when he understood what I said, he would nod with smile. But when he did not understand what I said, or when ha could not make himself understood by me, he was angry and badtempered. I often got frustrated when I saw my nephew being frustrated.” For Mnan, who was 37 months old, the youngest of seven children, his mother was planning for his use of cochlear implants to address the problem of communication. She stated, "After his hearing loss was diagnosed, we firstly considered his use of hearing aids. But till to now, it did not work well. At present I used natural gesture to communicate with children. Because he was very young, he could not hear well, speak well and understand well. Sometimes he understood the simple things I said, but for more complicated meaning, he had difficulty. When I had to tell something important to him, I used body language to let him understand or teach him hand by hand and force him to exercise again and again." Similarly Lulu's mother also commented the hardship of communication with children. But with the growth of children, new communication means of the written language to be used in communication. Luhua's mother mentioned improvement in communication 
between them by writing, "When Luhua was young, I experienced the frustration with communicating with her. But after she attended special school, he learnt sign language, and she taught me the sign language, so we can communicate more complicated meaning. Now she could write, we often used writing to express our ideas, so we felt communication between us easier." For three children with cochlear implants, their communications were in different context. Bao, who was implanted cochlear implants (CI) at the age of 22 months old, with the time of 31 months use of CI, having going through the long time of adaptation to CI and hearing speech training, he could understand the majority of what parent and teacher said. For Hang and Wang's families, they were struggling with exercising hearing and speaking to benefit more from hearing and speech training after the average 18 months of use of cochlear implants.

\section{Difficulty in family economy}

Even in western developed countries, some families report difficulty meeting the financial demands related to equipment or service including the cost of sensory devices, therapy, and early intervention programs etc. (Jackson et al., 2008). For these Chinese families from China, the largest yet still poor country, economic burden is the second biggest difficulty of families experienced following the communication difficulty.

Bao was a boy from a middle income family. His parents had job with stable income, and his grandparents could get pension because of retirement from the work. But the financial burden resulted from his hearing loss almost put his family into poverty. When asked the details of the money spent by his grandson, Bao's grandma collected: "firstly, my family paid the expense of newborn screening including hearing screening, then the family pay the money for the comprehensive audiological evaluation. I could not remember the exact money because it was paid by my son. After audiological evaluation, as a result of doctor's suggestion, we spent 15,000 RMB to buy hearing aids for Bao. But Bao did not benefit from this expensive device and he still had no response to sound stimuli. Afterwards we were told that maybe cochlear implants could work. However it was much more expensive than hearing aids, with price ranging from more than 140,000 to more than 200,000 RMB. Despite the price was far beyond the family saving, but with the belief that we should do everything we can to maximize Bao's development, we decided to sell our house for it. It was really lucky that in later time Bao became one of qualified targets of the National Cochlear Implants Program organized by the China Disabled Per- 
sons Federation and funded by Mr. Wang Yongqing, a famous industrialist from Taiwan. My family only paid more than 40,000 RMB for service related to cochlear implants operation and consequent hearing and speech training. However, comparing the money spent with our income, we still regarded it as a large amount expense."

Not as fortunate as Bao's family, Hang's family was deep in debt because of Hang's use of cochlear implants. According the description of Hang's grandma, when he was born in hospital, he was given newborn hearing screening and was tested as positive in hearing loss. When he was one and half years old, he was sent to hospital to test hearing loss and was diagnosed with profound hearing loss of more than $110 \mathrm{~dB}$. To help Hang's hearing, his family rent a hearing aid from the Chengdu Rehabilitation and Education Center with a small amount of money. But hearing aids did not bring any gain in hearing. They were then told that cochlear implants may help Hang. At that time, the cochlear implant made by Australia was well-known in local deaf community and its price was 148,000 RMB. Compared with the average overall income of 10,000 RMB annually, the cochlear implants was far beyond the family's financial affordability. However, the family still firmly made up their minds to implant the cochlear implants with the belief that they would do everything beneficial to their child at all costs. With the allowance of 56,000 RMB from the Chengdu Disabled Persons Federation, eventually the family paid 92,000 RMB for the operation of cochlear implant in 2008. Most of the money was borrowed from their relatives. One child's hearing loss let the whole extended family fall into debt.

Wang's family had similar experience to Hang' family. At present they were in heavy debt because of using cochlear implants. As for other three families, namely, Mnan's family, Lulu's family and Luhua's family, their economic conditions were depressed by children's hearing loss to larger or less extent. As main caregivers and mothers of three hearing impaired children, they had to stay at home to take care of children with the notion that hearing impaired children were more dependant on parental care than hearing peers. Because of only one breadwinner in families, the family income reduced. As Lulu's mother stated: "I could not go to city together with my husband to earn money like other mothers. My husband worked in city as a migrant worker all the year. He was the only breadwinner in my family. Because of my son's deafness, I could not leave him to his grandma. So my family economic condition was worse than other families who had more people to earn money in this village." The only family unaffected apparently by child's hearing impairment was Shuai's family. 
His family rented hearing aids from the CREC. His father had applied for the National Cochlear Implants Program for him, but was rejected eventually. At last he gave up the idea of implanting cochlear implants to his son because he thought it was not cost-effective.

\section{Difficulty in access to intervention services}

Due primarily to the large population of the country and the associated financial constraints China was facing there were few intervention programs which provided services, for example, information about hearing impairment and sensory device, funding sensory devices, social support to help family accept hearing loss, teaching sign language, etc. for the hearing impaired children and their families, if any, they were far from being accessible. In this study, Lulu and Luhua from the Luxian county, had never used hearing aids and cochlear implants despite their profound hearing loss, and their families reported they had never get any free social support from governmental agencies and professional institutions. Their children only could communicate with people surrounding them by sign language after they learnt in special school. Mnan's mother was worrying about the surgery of cochlear implants for his son but she only could get some information from parents. The main regular intervention services that the other four families from Chengdu city could get were hearing aids for rent and hearing-speech therapy provided by the CREC for disabled children. But the service of hearing-speech therapy was not easy accessible for Hang's family and Wang's family who lived in a suburb and Shuai's family who lived in a rural area. Hang's grandma shared her tough experience with interviewer, "because my family fell into debt for cochlear implants, all the family members had to save money as much as possible. It was valuable that the CREC could provide the associated hearing and speech training after cochlear implants, but it was extremely far from my home. On every Monday to Friday, I and Hang got up at 6 o'clock and walked one hour to bus stop, then after one hour's bus trip we could got to the CREC to start training. When Hang received training, I either stayed at the rest room or went out to wander in streets. Then at 4 o'clock in the evening we went back home following the same path. This life was hard, but it had lasted for more than one year, so we were already accustomed to it."

Difficulty in making decision

According to Jackson (2008), families of children often met difficulty in making decision in communication mode, sensory device and educational place- 
ment. The factors influencing decision making are mainly from parents' desire, information and health and safety concerns (Jackson, 2008). Comparing the data from seven families in this study with previous researches, a bit different conclusions were formed and presented in the following sections. From the surface, all of seven families reported that they seldom experience difficulty in making decision in choosing communication mode. All families expressed the common desire to maximize their children's hearing and speaking ability. When these caregivers were asked how they dealt with the difficulty in communication between them and children, six caregivers told interviewer that their families insisted on using spoken language mixed with natural gesture to communicate. Only Lulu's mother took initiative to educate herself sign language by reading the book Chinese Sign Language. As stated in Shuai's grandma' words, "The hearing and speech training provided by the CREC is in the form of oral mode, we must help Shuai exercise it at home. So we try our best to communicate with him in spoken language." In this study, no family really knew sign language and no caregiver had ever received systematic training in sign language. So, to some degree, it was not fact that they had no difficulty. More accurately, it should be said that they had no choice in making decision.

As for the choice of educational placement, the condition was similar to that of communication mode. All families reported they had no difficulty in making decision. Four families of younger children with or planning for cochlear implants gave a consistent comment that regular school was better placement than special school. To a larger extent this consensus could be put down to the lack of understanding of a special school. As Wang's grandma said, "I did not know a special school and I felt it was not good. I never thought of sending him a to a special school." Mnan's mother emphasized that the purpose of implanting a cochlear implants was the opportunity to attend a regular school. She stated, "Regular school was certainly better choice for my children. But if he could not get good hearing by cochlear implants, the special school was acceptable. Yet in that case, the money we spent in cochlear implants was wasted." In contrast, three families of children without using cochlear implants had another consensus. Luhua's mother said, "The special school was beneficial for my daughter. There she has learned sign language and got literacy. She also could communicate with peers with similar experience in the special school." Similar to Luhua's mother, both Shuai's aunt and Lulu's mother emphasized the importance of attending the special school. In their opinion, the best choice for children who could not communicate by the oral approach was the special 
school where they could communicate with sign and got education appropriate to them.

For three families of children using cochlear implants making decision in cochlear implants was not fully evidenced-based. Lacking of appropriate information from professionals, they made decision by trial and error and experiences from other parents. When asked why at last they chose cochlear implants as sensory device, the explanation from Bao's grandma and Hang's grandma was: "It was a result of trial and error. When hearing aids could not work, we only could choose cochlear implants. We were not sure of its effect, but it was the last hope." However, Wang's family was another case. Wang's grandma stated, "Wang did not go through a tryout of hearing aids before he was implanted cochlear implants. When we first went to the hospital to diagnose his hearing loss, we had met and talked with a parent of a child who firstly used hearing aids and then was implanted cochlear implants when hearing aids did not bring a great gain in hearing. When we went to the hospital second time to get the diagnosis we met another parent of a child with cochlear implants and asked about its effect, we were told it was not ideal but better than nothing. After that Wang's father searched some information from internet. At last, the family decision was made that cochlear implants would be implanted without trying of hearing aids to avoid the money being wasted." When participating this study, Mnan's mother was considering his son's surgery of cochlear implants and have somewhat worry about the invasive nature of surgery. However, regardless of her health and safety concern, her decision had been firmly made.

\section{Strategies of family coping with childhood hearing impairment}

Living within a social context which was of no solid social security system, these Chinese families used their unique strategies to deal with various life challenges or difficulties caused by childhood with hearing impairment. The following story line was demonstrated by integrating the relevant concepts appeared in the conversations.

Bao's family was the most resilient case according to our understanding of resilience. This family completely consisted with the standard of accepting well, functioning well and expecting well. When Bao's grandma was asked how her family went through these years, she elaborated their experience of restructuring their family to gear toward optimizing Bao's potential in behalf of her family. She stated with a bit pride: "In the early time when we were told the diagnosis we really felt the sky collapsed. We embraced together and cried. $\mathrm{He}$ 
was the only child in this extended family. We felt extremely unprepared for his hearing loss and uncertain about his future. Fortunately my family was closely connected. My son and my daughter-in-law never quarreled for the child's hearing loss. To reduce their time demand I and Bao's grandpa took initiative to be responsible for taking care of Bao's life while my son and my daughter-in-law went on with their work to earn more money. Before the child was born, my daughter-in-law had planed to stay at home to care of her child by herself after the child's birth. Things changed greatly because of the hearing loss. Firstly we were overwhelmed with an unexpected handicap, then with the challenge of a large amount of money for hearing aids and followed by the hearing aids' failure. More fortunately, we were informed of the National Cochlear implants Program by the CREC and got the donated cochlear implants after his passing multiple examinations including the intelligence test, hearing and speech test and test of adaptability to cochlear implants. After using cochlear implants, Bao also could go to the CREC to receive free service of hearing speech training on week days. Over years all family members tried our best and didn't miss any opportunity for the good of Bao. In the daytime of every weekdays his parent go to work while I and his grandpa take him to go to the park or go to the CREC to receive hearing and speech training. At night his parents help him exercise what he had learnt at the center and we couple could have a sound rest. This process was not easy but fruitful. Before Bao attended regular preschool he was assessed by the professionals in the CREC as a top hearing-impaired child with high intelligence, second grade of speech ability, a degree which was understood as with capability of communicating with people around them basically. Speaking of Bao's near typical level of development, we really wanted to express thanks to those who gave us help. They were the CREC and their teachers in the CREC, those parents with similar experiences to us, our neighbours and relatives, Mr. Wang Yongqing who donated the cochlear implants, and all the families members who stood together to turn the tragedy into comedy. We all hoped that Bao would be contributing member to redound upon society."

Other six participants expressed the similar experience of difficulty in parenting and at last adapting to the challenges positively. Wang's grandma-in-law accepted Wang's handicaps as her family's destiny. "His coming to the world was asking us to pay the debt we owed in previous existence. Now all the families were working together to earn more money for clearing debt due to cochlear implants and preparing for his future." Hang's grandma accompanied by Hang had been walking in the long distance between the CREC and their home day 
after day while Hang's parents were busy with earning more money for his future life. Shuai's aunt repeated again and again that Shuai's parents should devoted more time to take care of their son by themselves. However, Shuai's parents were occupied with their business with belief that enough money could guarantee Shuai's security in the future life. Mnan's mother did not worry about family economy because of higher income from her husband and she was planning the operation of cochlear implants for her son with optimistic expectation that cochlear implants would help Mnan greatly. Lulu's mother from the countryside were educating herself Chinese sign language by reading book Chinese Sign Language to overcome the communication barrier between her and her son. Similarly, Luhua's mother, also from the countryside, felt gratified with her daughter who had learned sign language in a special school and could communicate with her fluently using language and writing. All these families went through the hoops and were functioning well. Despite they all worried about their children's future, they all believed that their children should have their own future.

Connecting the Walsh's (2003) conceptual framework of family residence to the experiences of participant families, the strategies which these families used to cope with life challenges were categorized into categories of accepting what can not be changed, cooperative parenting, making using of social resources, taking concrete steps towards goals.

Accepting what can not be changed. All but one caregiver expressed complete acceptance of children's hearing loss. Seven families explained the reason for their acceptance. Bao's grandma stated, "Although his profound hearing loss let us in hot water in the early days, eventually his loveliness and striking progress after using cochlear implants let us out of it. Now I did not think it was very bad thing." From another prospective, Hang's grandma explained her acceptance. She stated, "Now that it was our fate, we just accepted it." Similarly, Lulu's mother felt children's handicap was his destiny. Mnan's mother and Luhua's mother shared the same idea, as they stated, "It is the irreversible reality, you cannot change it." Only Wang' grandma reported the partial acceptance of her grandson's handicaps, as she described, "Sometimes when I felt tired, I could not accept it. But I knew accepting reality was helpful for all of us."

Cooperative parenting. The category of cooperative parenting discussed here meant two or more caregivers taking part in fostering children. In terms of the shared experience from participant families it greatly reduced the increased time demand and physical fatigue resulted from an additional burden of caring 
of handicapped children. In this study, five of seven hearing-impaired children were co-fostered by parents and caregivers from their extended families. Only Lulu and Luhua, from the Luxian Countryside, were mainly brought up by their mothers while their father, the main breadwinner of families went to cities as a migrant worker to earn money.

Mobilizing social networks. When asked what supports from social networks families had got to help them cope with the children's hearing impairment, except for Bao's family and Hang's families, other five families expressed that they did not get adequate support from social networks which were understood by participants as public welfare agencies. In fact, all seven families utilized more or less supports from inside and outside of families demonstrated in their conversations. Analyzing their experience, families had got economic, emotional, and parenting support from extended family, relatives, other parents with similar experiences, rehabilitation center (CREC), special schools, regular preschools. Table 4 detailed the main sources of support which families had got.

Table 4 The main social resources which give families support

\begin{tabular}{cccccccc}
\hline Social resources & $\begin{array}{c}\text { Bao's } \\
\text { family }\end{array}$ & $\begin{array}{c}\text { Hang's } \\
\text { family }\end{array}$ & $\begin{array}{c}\text { Shuai's } \\
\text { family }\end{array}$ & $\begin{array}{c}\text { Mnan's } \\
\text { family }\end{array}$ & $\begin{array}{c}\text { Wang's } \\
\text { family }\end{array}$ & $\begin{array}{c}\text { Lulu's } \\
\text { family }\end{array}$ & $\begin{array}{c}\text { Luhua's } \\
\text { family }\end{array}$ \\
\hline Extended family & $\bullet$ & $\bullet$ & $\bullet$ & $\bullet$ & $\bullet$ & $\bullet$ & \\
$\quad$ Relatives & $\bullet$ & $\bullet$ & & $\bullet$ & & & \\
Other parents & $\bullet$ & $\bullet$ & $\bullet$ & $\bullet$ & $\bullet$ & & \\
Rehabilitation center & $\bullet$ & $\bullet$ & $\bullet$ & $\bullet$ & $\bullet$ & & $\bullet$ \\
$\quad$ Special school & & & & & & $\bullet$ & $\bullet$ \\
Regular preschool & $\bullet$ & & & & & & \\
\hline
\end{tabular}

Focusing on the goal and taking concrete steps. All seven families held the hope that their children would not have a not very bad future and could survive, be independent on others in adulthood. In order to reach their hopes, all the families took their own steps. The common point across families was earning more money for children's future. Other concrete steps included buying or renting hearing aids, implanting cochlear implants, implementing family training, participating in hearing and speech training, learning sign language etc. Table 5 listed the concrete steps families taken toward children's future. 
Table 5 Families' steps taken towards children's future

\begin{tabular}{|c|c|c|c|c|c|c|c|}
\hline $\begin{array}{l}\text { Steps towards } \\
\text { future }\end{array}$ & $\begin{array}{l}\text { Bao's } \\
\text { family }\end{array}$ & $\begin{array}{l}\text { Hang's } \\
\text { family }\end{array}$ & $\begin{array}{l}\text { Shuai's } \\
\text { family }\end{array}$ & $\begin{array}{l}\text { Mnan's } \\
\text { family }\end{array}$ & $\begin{array}{l}\text { Wang's } \\
\text { family }\end{array}$ & $\begin{array}{l}\text { Lulu's } \\
\text { family }\end{array}$ & $\begin{array}{l}\text { Luhua's } \\
\text { family }\end{array}$ \\
\hline $\begin{array}{l}\text { Using hearing } \\
\text { aids }\end{array}$ & - & - & - & - & & & \\
\hline $\begin{array}{l}\text { Using cochlear } \\
\text { implants }\end{array}$ & - & - & & & - & & \\
\hline Family training & - & & & & & & \\
\hline $\begin{array}{l}\text { Hearing and } \\
\text { speech training }\end{array}$ & - & - & - & - & - & & \\
\hline $\begin{array}{l}\text { Learning sign } \\
\text { language }\end{array}$ & & & & & & - & - \\
\hline $\begin{array}{c}\text { Earning more } \\
\text { money }\end{array}$ & • & • & • & • & • & • & - \\
\hline
\end{tabular}

\section{Limitations of research}

Reflecting the research process of this study we sensed that each research conducted was compromise between an ideal plan and the reality. The most apparent limitation of this research was the small number of participants due to constraints of time, energy, availability of subjects. Despite lack of clear regulations on the number of participants in qualitative research, "it was safe to state that the researchers should continue to collect and analyze data until theoretical saturation takes place." (Corbin \& Strauss, 2008, p. 324). It was clear that seven families were far from the status of theoretical saturation. However, through the limited participant families, some voices from hearing-impaired families had been heard. Considering the heterogeneity and large number of hearing-impaired population in China and the disparity in development between urban and rural locations and among regions, it is desired that more families from culturally and linguistically diverse backgrounds with children of different age, different severity of hearing loss and in different educational placement will be involved in future researches and more varied voice will be heard.

\section{References}

CORBIN, J., STRAUSS, A. (2008). Basics of qualitative research: techniques and procedures for developing grounded theory, $3^{\text {nd }}$ ed. London: Sage Publications, Inc. 
GREGORY, S., KNIGHT, P. (1998). Social development and family life, in Issues in Deaf Education, Gregory, S., Knight, P., McCracken, W., Powers, S., and Watson, L., London: David Fulton Publishers.

HAAN, L. D., HAWLEY, D. R., \& DEAL J. E. (2002). Operationalizing family resilience: a methodological strategy. The American journal of family therapy, 30: 275-291.

JACKSON, C. W., TURNBULL, A. (2004). Impact of deafness on family life: a review of the literature. Topics in early childhood special education 24:1, 15-29.

JACKSON, C. W., TRAUB, R. J., TURNBULL, A. P. (2008). Parents' experiences with childhood deafness: Implications for family-centered services: Communication disorders quarterly. Austin: Feb 2008, Vol. 29, Iss. 2, 82-99.

MARSCHARK, M., HARRY, G. L., ALBERTINI, J. A. (2002). Educating deaf students from research to practice. New York: Oxford University Press, Inc.

MURPHY, D. A. \& MARELICH, W. D. (2008). Resiliency in young children whose mothers are living with HIV/AIDS, AIDS care, Vol. 20(3), Mar 2008, 284-291.

Office of United Nations High Commissioner for Human Rights (1989). Convention on the Right of the child, Retrieved from http://www2.ohchr.org/ english/law/crc.htm.

PATTERSON, J. M. (2002). Integrating family resilience and family stress theory. Journal of marriage and family 64 (May 2002), 349-360.

STRAUSS, A., CORBIN, J. (1998). Basics of qualitative research: techniques and procedures for developing grounded theory, $2^{\text {nd }}$ ed. London: Sage Publications, Inc..

WALSH, F. (2003). Family resilience: a framework for clinical practice. Family process, Vol. 42, No. 1, 1-18.

WERNER, E. E. (1995). Resilience in development. Current directions in psychological science. Vol. 4(3), Jun 1995, 81-85.

\section{Contact:}

Liu Shenglin,

Institute of Special Education,

Faculty of Education, Palacký University,

Olomouc, Czech Republic,

e-mail: xiaoduo.liu@gmail.com 